\title{
Grassroots Expertise at a New York City Community Board
}

\section{Tom Waters, Political Science, CUNY Graduate Center October 4, 2017}

In New York City and across the United States, neighborhood councils established by local governments are incorporating citizen participation into decision making while engaging issues that require them to use expert knowledge. These participatory projects can be seen as a way to check the pervasive and potentially undemocratic role of expertise in society, by creating a public setting in which experts' advice can be exposed and criticized, and in which laypeople can attempt to influence policy processes that would ordinarily be dominated by experts. This ethnographic study investigates the fine-grained human interactions as members of a New York City community board in a low-income neighborhood engage land use and housing issues. It finds that they can partially overcome the challenge of expertise by developing their own technical capacity, and that this enhances board members' influence. But it also finds that members encounter difficulties that cannot be remedied by more technical capacity. First, board members who develop expertise still lack complementary instrumentalities, such as access to insider information. And second, they find it difficult to juggle performance of their expert role with other roles they must play in their deliberations, especially the role of representing the community, which is essential if they are to influence elected officials through public opinion.

In cities across the United States, neighborhood councils established by local governments are incorporating citizen participation into decision making while engaging issues that require them to use expert knowledge. Democratic theory suggests that participatory processes can be an alternative to the undemocratic power of experts, but also that participation can be undermined through the illegitimate influence of expertise within the processes themselves.

Empirical work on neighborhood councils has paid relatively little attention to this problem, focusing instead on such issues as the ability of participatory projects to overcome distrust or to identify and aggregate interests across social divisions. The most recent American studies have tended to find that participation does not effectively increase the influence of political outsiders (Lee, McQuarrie, and Walker 2015, Levine 2017), while British studies (often focused on urban redevelopment) have found that participation's effectiveness depends on power relations beyond the projects themselves (Jones 2003, Swyngedouw 2005, Taylor 2007). Recurring themes of these skeptical views are the unclarity of the projects' goals, the discretion of sponsors and facilitators in 
shaping their processes, and the dubious representativeness of the participants, as well as pressure on participants to "internalize[e] the values and purposes of their new peers" within the process (Taylor 2007).

Expert knowledge is a pervasive influence in modern society with the potential to bias democratic decisions, especially when experts exert their influence within a bureaucracy, outside of public view and not subject to public legitimation (Turner 2001). We might like neighborhood councils and other participatory projects to serve to check the role of expertise by creating a public setting in which experts' advice can be exposed and criticized, and in which laypeople can attempt to influence policy processes that would ordinarily be dominated by experts. Some sociologists of science have found reasons for optimism about this. Ordinary people without expert credentials can and do participate in decision making processes with experts, influencing or contesting decisions and thus helping to legitimate them - at least when the conditions are right. Both the reception of expert knowledge by uncredentialled people (Wynne 1992) and the ability of the uncredentialled to effectively convey their own experience-based knowledge to experts (Epstein 1995) depend on the social settings and relationships within with these communications are attempted. These interactions work best when sympathetic credentialed experts act as mediators and or when uncredentialled "experience-based experts" learn the language of the credentialled ones (Collins and Evans 2002).

Arrayed against these optimistic views are persistent concerns of democratic theorists since Dewey (1927). They have identified several very plausible mechanisms by which expertise can distort this kind of communication: some participants may have far greater ability than others to use technical expertise as a persuasive resource; technical proficiency may mark some participants as having higher status than others; and value-laden technical discourse may distort decisions even behind the participants' backs. (Young 2000, Fung and Wright 2001, Gaventa and Cornwall 2001, Dzur 2004, Hayward 2004). The question about neighborhood councils then becomes an empirical 
one: not whether they can in principle make democratic use of expert knowledge, but what happens when they try to do so. Do the councils in fact provide a context in which meaningful exchange is possible between credentialed experts and grassroots participants? Do these exchanges make it possible for participants to influence, contest, or legitimate expert decisions?

This article investigates the use of expertise among grassroots members and staff of one neighborhood council in New York City, Manhattan Community Board 11 in East Harlem, as they seek to influence land use and housing decisions - fields in which expert discourse is highly legitimate. It finds that, as expected, the salience of expertise in these deliberations shapes inequality of influence. It further finds that board members respond by using technical information provided by experts, by developing their own technical capacity, and also by adhering to a style of self-presentation that seems appropriate to an expert advisory role. It also finds evidence that their deliberations on technical matters can influence authoritative decision making because of the boards' role in legitimating public opinion in a way that matters to elected officials, especially City Council members. This channel of influence is strengthened by the relative clarity of the board's constituency, resources, and powers under the New York City Charter, compared to many other participatory institutions in contemporary governance.

Perhaps most important, it finds that the board's use of expertise is effective up to a point, but that two barriers limit effectiveness in ways that more technical capacity cannot remedy. First, board members who develop expertise still lack complementary instrumentalities, such as access to insider information. And second, they find it difficult to juggle performance of their expert role with other roles they must play in deliberations, especially the role of representing the community, which is essential if they are to influence City Council members through public opinion. Both these mechanisms involve both the fine-grained social interactions that take place within the Community Board and the links that connect the board to city agencies, elected officials, and other players. Although New York's community board system has unique features and the East Harlem board Grassroots Expertise - 3 
members have more technical capacity than usual for low-income neighborhood councils, the challenges of role conflict are likely to be present in councils in other contexts.

\section{New York's Community Boards}

New York's community boards work within better defined parameters than many other participatory projects. Each board has a precisely defined territory and constituency, a defined membership appointed through a public process, and defined outputs that are advisory but public. They have been operating for decades, and are widely recognized as significant fora within their neighborhoods. Since 1975, the New York City Charter has authorized community boards representing 59 geographic districts and granted them the power to review, to advise, to investigate, and to inform, though not to make authoritative decisions. The charter specifies 20 distinct functions for the boards, focusing on city services, the city budget, and most importantly, "initial review of applications and proposals of public agencies and private entities for the use, development, or improvement of land located in the community district" (NY City Charter $§ 2008 \mathrm{~d}$ (1) and d (17)). The boards are oriented toward public executive and legislative authority. Though

they operate in a field with many private organizations and bureaucratic agencies, they are closely linked to elected officials and seek to exercise influence through them. The city's borough presidents appoint all board members, half of them designated by city council members. These elected officials have the power to select members with whom they expect to agree and to remove them at the end of their two-year terms if they turn out to disagree. Occasionally this power has enabled elected officials to determine the outcome of specific board decisions (Williams 2006).

The city's community boards represent a considerable investment of money and volunteer effort, attracting the efforts of thousands of the city's most politically active people. They average 46 actual members, out of a maximum of 50 , and an average of three quarters of the members attend 
an evening meeting each month. ${ }^{1}$ Members include leaders of community organizations, tenant associations, advocacy groups, labor unions, and political clubs, as well as business people and staff of service organizations. The activities of the boards go far beyond mandated monthly meetings. Each month, the East Harlem community board holds 18 scheduled meetings of committees, standing subcommittees, and other bodies, in addition to its full board and executive committee meetings. Boards also hire their own staff. The East Harlem board has three full-time staff members and makes use of planning consultants and other sources of technical assistance. Citywide, the government budgets $\$ 15.2$ million for board operations, plus $\$ 1.2$ million for a mayoral office that supports the boards, and borough presidents' offices, the Department of City Planning, the Independent Budget Office, and private philanthropies provide additional support (Office of Management and the Budget 2011). These resources are dwarfed, however, by the capacity of the city agencies and private developers whose activities the boards seek to influence.

The community boards were established during a period when neighborhood councils were becoming more common throughout the United States. Intellectuals of the left and right saw these councils as sites for the renewal of active citizenship (Looker 2015), while city administrations saw them as a constructive response to concerns about urban renewal and a way to combat public disaffection, especially in low-income black and Latino neighborhoods (Yates 1973, Advisory Commission on Intergovernmental Relations 1979). During subsequent decades, city governments continued to create neighborhood council schemes in an effort to connect citizens with government and improve declining public trust (Cooper, Bryer, and Meek 2006; Jun and Musso 2013). But despite the consensual drift of these ambitions for neighborhood councils, observers of New York City's community boards have focused on the boards' conflictual side, noting both internal conflicts

${ }^{1}$ The average board size was taken in 2012 from the 48 boards for which recent memberships could be found online; the attendance rate is averaged from the rates at recent meetings of 27 boards for which recent minutes including attendance or recorded votes could be found. Lower-income districts tend to have fewer members appointed, and that geography affects both the number of members appointed and the attendance rate, with noticeably fewer members showing up in the Bronx and Queens.

Grassroots Expertise - 5 
and those between neighborhoods and "downtown" pro-growth interests (New York City Affairs 1980, Marcuse 1987, Marcuse 1990, Pecorella 1994, Davila 2004, Hum 2010). The strictly advisory role of New York's community boards places them on the "placation" rung of Arnstein's (1969) ladder of citizen participation, but scholars have argued that participation can be influential even in the absence of formal authority (Berry, Portney, and Thompson 1993, Chaskin and Abunimah 1999, Fung 2006). Marcuse (1990) argues that gentrification has given the boards a degree of power since the 1970s, as developers and politicians sought the boards' support for development projects in changing low-income areas. Pecorella (1994, p. 194-5) concludes that "the boards are merely advisory, but they have opened land-use review in New York to public scrutiny," suggesting that their limited formal powers give rise to a consequential informal influence.

\section{Research Setting and Methods}

Manhattan Community Board 11 represents the neighborhood of East Harlem, a historically low-income area that is now being affected by market-oriented as well as subsidized real estate development. It is generally seen as a Puerto Rican neighborhood, but has also long had a substantial African-American population and now has a growing number of Mexican-born and other residents (Davila 2004). East Harlem has the city's largest concentration of public and subsidized housing (46 percent of the occupied housing stock) and one of the poorer populations (44 percent of households below 200 percent of the poverty threshold - 15th largest share out 55 Census Bureau-defined sub-borough areas). ${ }^{2}$ The rents on its private unsubsidized apartments, however, are in the city's middle range, and the median contract rent for recent movers, reflecting the current housing market, is well above the middle. Beginning in the 1990s, more than 5,000 subsidized rental apartments have been created in the district, ${ }^{3}$ much of it using vacant buildings

\footnotetext{
2 These figures are calculated from the 2011 New York City Housing and Vacancy Survey.

${ }^{3}$ Calculated from data from the Furman Center for Real Estate and Urban Policy's Subsidized Housing Information Project, available at furmancenter.org/data

Grassroots Expertise - 6
} 
and land abandoned by owners in previous decades. Developers have also built a significant amount of market-rate and owner-occupied housing.

From February to May 2012, my participant observation included attending three meetings each of the full East Harlem Community Board, its Housing Committee, and its City Properties and Land Use Committee. I volunteered at the board's office for a morning or afternoon each week for ten weeks, examined minutes and other records, and conducted six formal interviews and a number of informal ones. I did not appear as a disinterested observer. My previous work as a policy analyst and advocate had already brought me into contact with several board members and staff. This allowed me to immediately begin interactions focused on policy information-processing, carrying out simple analytic work and occasionally taking advocacy positions on the issues before the board.

\section{The Search for Expertise}

The affordability of housing that developers propose to build in the district is a central technical issue for the East Harlem community board. Can the district's actual residents afford the proposed housing? This question has both an experiential and a technical aspect. Many community members are well aware that they and their neighbors cannot afford the new housing, but they lack knowledge of Census rent and income statistics and thus have difficulty putting their understanding into a form that is legitimate in policy discussion. They also lack the knowledge of housing policy and finance needed to compare the affordability profile of a given housing proposal to realistic alternatives. As a result, board members are driven to seek expertise in order to articulate the needs of the community they represent. When board members obtain "interactional expertise" (Collins and Evans 2002) pertaining to housing subsidy programs and the Census data commonly used in discussions of affordability, they can undermine the technical ownership of the income targeting issue by credentialed experts such as developers and agency officials. But this means little to board members unless they can improve their influence on the affordability of housing 
developments in their district, and this depends on many other factors. My volunteer work at the board's offices allowed me to observe, and contribute to, the board's efforts to translate the need for housing affordable at lower income levels into realistic and technically legitimate responses to specific proposals. Although the board welcomed my additional information and processing capacity, my contribution had little obvious impact, because the board was less constrained by a need for better information about their own community's needs than by a lack of information about other parties' preferences and capabilities.

Most housing proposals presented to the East Harlem community board for review come from private developers seeking to build with multiple subsidies channeled through city agencies, especially the federal Low Income Housing Tax Credit. In return for the subsidies, developers agree to rent some or all of the new or renovated apartments to households with incomes in certain ranges, and to charge correspondingly affordable rents. Each subsidy program has its own income limits, which are expressed as percentages of the Area Median Income. The federal Department of Housing and Urban Development calculates this "AMI" by finding the median income for the city plus the northern suburbs of Westchester, Putnam, and Rockland counties, then adjusting upward based on the area's high housing costs. The AMI is much higher than the city's actual median income, let alone the median for a low-income neighborhood like East Harlem. Thus apartments set at 50 percent of AMI, a typical level, are available to households with incomes around than $\$ 38,000$ a year for a family of three, close to the city's median and far higher than the East Harlem median.

On my first day at the board's offices, District Manager George Sarkissian and Assistant District Manager Angel Mescain showed me a list of tax credit developments that were either recently completed or under construction. After this conversation, they asked me to examine the board's file for one of these projects, a development known as 1951 Park. The folder contained four documents relating to the board's role in the city's land use review process, its key formal involvement in development proposals. The documents were:

Grassroots Expertise - 8 
- HPD's notice of the proposal and an attached Environmental Assessment Statement, prepared by a consultant.

- The letter from the board to the Manhattan borough president, signed by the board chair, supporting the project.

- City Planning Commission forms for the project, filled out by the board and signed by the chair.

- A checklist, designed by the board and filled in by the developer. The checklist included instructions, an explanation of what the board required in order to extend support, five pages of questions for the developer, and one page with spaces to be filled by the district manager, the land use committee, and the full board.

The checklist was not complicated but did indicate that the board was taking an active role in the approval process. The board had recently approved another development only after initially rejecting it and then joining with the local city council member in negotiating a new proposal. The files for this project contained more materials, reflecting the greater degree of board involvement, including a letter memorializing the agreement and some handwritten notes from face-to-face meetings. Neither folder contained any independent research material, however. It was clear that even at its most involved, the board depended on other interested parties for information. The information dependency reinforces the board's tendency to "play defense" when vetting proposals generated elsewhere instead of generating an affirmative development vision of its own.

The 1951 Park proposal gave me an opportunity to contribute to the board's information processing. The Environmental Assessment Statement for the project described the affordability of the apartments in the proposed development, which would include:

- 63 apartments for households with incomes up to 40 percent of the Area Median Income, which comes to about $\$ 32,000$ a year, roughly the median for the community district. - 186 apartments for households at the higher level of 40 percent to 60 percent of AMI.

- 63 apartments for households from 80 percent to 130 percent of AMI.

Only 20 percent of the apartments in the project would be affordable even to residents in the middle of the district's income distribution, revealing how poorly present-day affordable housing developments match the needs of low-income neighborhoods. But 1951 Park actually does better than most. This led me to take a closer look how this project's income targeting fit within the community's income profile, using data downloaded from the Census Bureau's website. My analysis Grassroots Expertise - 9 
divided the neighborhood's population into income bands comparable to the ones used in allocating subsidized apartments, then calculated how the number of apartments in the 1951 Park project for each income band related to the number of households (in thousands) in that band in the local population (Figure 1). The project disproportionately benefits households just above the neighborhood's median income, with a secondary concentration for those just above the local 75th percentile. The poor are shut out, as usual.

Figure 1: Affordability at the 1951 Park Avenue development

\begin{tabular}{|l|r|r|r|r|r|}
\cline { 2 - 6 } \multicolumn{1}{c|}{} & \multicolumn{2}{c|}{ East Harlem Community } & \multicolumn{2}{c|}{ Proposed Project } & \multicolumn{1}{c|}{$\begin{array}{c}\text { Ap'ts Per } \\
\text { Thousand }\end{array}$} \\
\cline { 2 - 6 } \multicolumn{1}{c|}{} & Households & \multicolumn{1}{c|}{ Share } & Apartments & \multicolumn{1}{c|}{ Share } & \\
\hline $\begin{array}{l}\text { Up } \mathbf{4 0} \text { percent of } \\
\text { “Area Median } \\
\text { Income" }\end{array}$ & 22,912 & $51.2 \%$ & 63 & $20.1 \%$ & 2.75 \\
\hline $\mathbf{4 0}$ to $\mathbf{6 0}$ percent & 6,948 & $15.5 \%$ & 188 & $59.9 \%$ & 27.06 \\
\hline $\mathbf{6 0}$ to $\mathbf{8 0}$ percent & 4,067 & $9.1 \%$ & 0 & $0.0 \%$ & 0.00 \\
\hline $\mathbf{8 0}$ to $\mathbf{1 3 0}$ percent & 5,969 & $13.3 \%$ & 63 & $20.1 \%$ & 10.55 \\
\hline $\mathbf{1 3 0}$ percent plus & 4,844 & $10.8 \%$ & 0 & $0.0 \%$ & 0.00 \\
\hline TOTAL & 44,740 & $100.0 \%$ & 314 & $100.0 \%$ & 7.02 \\
\hline
\end{tabular}

Source: American Community Survey 2006-2010 for Public Use Microdata Area 3804.

When the board's staff saw this analysis two weeks later, Sarkissian found it useful but not surprising. My reaction was that it might be a little unfair to the developers, because they did not determine the income eligibility bands, which are set by the subsidy programs and the amount of subsidy that HPD decides to give them, but Sarkissian cut me off and told me that this was too charitable to the developers, who can decide how much subsidy, and which forms, to seek. He pointed out that during the housing boom, developers were bringing projects that had far fewer affordable apartments than they did in 2012, typically 50 percent market, 30 percent middle income, and 20 percent low income. The 2007 housing market collapse exposed something that the 
board might not have been able to determine any other way - that developers could make a profit even with much larger affordable components than had been on the table during the boom.

Developers do not formally need the board's support to go forward, but they seek it because the board's decision shows legitimate community support for their plans. This gives the board leverage in pursuing its preferred outcome, which during the time of this study was maximum affordability. Expertise is part of a strategy for using that leverage, and so is a degree of judiciousness in its granting or withholding of approval. By discriminating between proposals that maximize affordability and those that don't, rather than simply opposing all proposals as insufficiently affordable, the board shows that it is a sound representative of the community's true interests. The board's checklist helps it to develop and demonstrate its expertise and to bring it to bear on specific proposals. But the major uncertainty facing the board concerns how much affordability they could attain. To find out, the board would need access to information about developers' costs and the availability of subsidies. Otherwise, even the most capable board can do little more than engage in brinksmanship with developers and agencies in order to determine the highest level of affordability attainable. Expert judgment on whether a development proposal provides good enough affordability profile given the limitations of their policy environment requires access to information guarded by other parties, especially developers. Knowing their own community, and translating that knowledge into an expert discourse, is not sufficient to display this kind of judgment. Analyses like mine are useful for demonstrating the need to get more out of any given proposal, but they do not overcome the information asymmetry and the board's defensive position with respect to developers and agencies.

\section{The Limitations of Expertise}

Board members use of expertise went beyond facilitating interaction with credentialed people, however. They also consistently sought to adopt a style of behavior appropriate to experts. 
Given the community board's advisory role, it makes sense that members would seek to present themselves this way even when they want to control, rather than merely inform, city agencies. After all, many of the most trusted advisors are experts. The expert style of self-presentation that they adopted sometimes enable board members to interact effectively with other players. In one meeting between the board's City Properties and Land Use Committee and officials from two city housing agencies, the expert style did appear to help members as they sought to test expert claims made by agency officials, but it was unclear whether this led to any effective influence. During the meeting, members used their charter-specified powers to obtain information and provide advice, they displayed a high degree of technical competence, and they prevented agency officials from using technical matters to obfuscate the issue they wanted to address, but they were unable to establish that they had achieved any effective influence over the agencies. ${ }^{4}$

The committee had invited officials from the Department of Housing Preservation and Development (HPD) and the Housing Development Corporation (HDC) to one of its regularly scheduled meetings to discuss the implementation of the city's "community preference" policy, which requires developers to give residents of the district first access to half the apartments in new subsidized developments. In East Harlem, far fewer residents actually obtain apartments, because not enough apply and are found qualified. Mescain told me that developers often take out only one local advertisement and don't do anything else to promote developments. In one example, a developer had given residents a 30-day window to request an application form by mail, receive it, and then mail it back in - all during the Christmas holiday season. The board responded to this problem by getting the 1951 Park developers to agree to a marketing plan with a longer timeline,

${ }^{4}$ This was not the case in every interaction with technically able outside parties, however. On another occasion, I observed a board committee questioning a developer about the partnership arrangements underlying one proposed development. Although some committee members had a general knowledge of the type of arrangements under discussion, most did not, and it appeared that the committee's collective expertise was not sufficient to produce a successful interaction. 
more advertising, and cooperation with community organizations. The plan worked, and local residents obtained their full share of the apartments. Board members and staff considered this to be one of their better victories. Now the committee had asked officials to discuss institutionalizing the marketing plan for future developments, not only in East Harlem but citywide. ${ }^{5}$

The meeting took place in a sparsely furnished community room in a senior housing development. Eleven members of the committee sat at a group of plastic folding tables arranged in a U formation, while another eight people sat in rows of folding chairs set up opposite the tables. The attendees were dressed casually but respectably and in some cases rather stylishly. Most of attendees seemed to be wearing their work clothes, but not if they worked at places where clothes get dirty or connote low status. Two of the three expected city officials arrived twenty minutes late after getting lost in the neighborhood. The committee began with brief other business, but once the officials were ready, committee chair Tanya Smith turned the meeting over to Michelle Miller of HPD. Miller began by saying that the agency was excited about the Community Board's marketing plan, but that they would begin with a Powerpoint presentation on their own plan. Bob Morris of HPD's marketing office then spent 20 minutes going over a detailed description of the process of applying for an apartment. This was not what the committee had asked from the agencies, but all of the members paid close and polite attention and several asked follow-up questions when Morris was done. Finally, Smith asked if there was any penalty for developers who fail to meet the target of 50 percent of all apartments rented to community district residents. Claudia Diller of HDC's marketing office responded that there was not, but that developers had to prove they did outreach to try to inform residents about the opportunity to rent. Smith followed up by asking who monitors

${ }^{5}$ Since the time of this study, HPD has moved its application process onto an internet platform, making it easier for prospective tenants to find out about and apply for apartments in multiple developments. This has resulted in much larger pools of applications for all developments, including both neighborhood residents and non-residents.

Grassroots Expertise - 13 
that, and Morris said that the "developer has a marketing plan submitted to us for review," and has to prove they contacted community groups.

Chairwoman Smith's tone of self-presentation in this exchange was the one that predominates in board activities - verbal, efficient, and business-like, with only the most limited hand gestures. This style of communication emphasizes the grammatical third person. Like other board members, Smith strove to present issues in terms of their general significance for the community. Even when board members have first-hand experience with issues, they rarely use this as a source of moral authority, as grassroots community activists often do in other contexts. The City Charter give board members a representative function, which might seem to call for a firstperson style of communication, but by positioning the board as advisory, it implicitly invites board members to function as experts. This evidently calls for the use of third person, and it was this aspect of the board's role that usually seemed to predominate.

Smith then asked why so many developers had failed to meet their community preferences. Morris replied that "we're aware of the difficulties in Community Board 11, and we always have been." One problem, he said, is that the income eligibility bands for these developments, based on the HUD Area Median Income system, are much higher than most East Harlem incomes. "Frankly," he said, "we're not building developments that target 20 to 30 percent of AMI." Smith replied by saying that many of the developments are quite small. They don't need to find a lot of eligible households, just a few. "That is a failure, a complete failure," she said. Morris began to say a few words, but another committee member, Andrea Boston, chimed in. “I don't get it,” she said. “They're not living up to their obligation." She asked again about monitoring of developers' marketing efforts. Diller explained that the agencies have logs of reported efforts, but not complete records. Boston said that they should audit the developers. "We do audit," Diller replied.

In this exchange, city officials sought to use a technical reason to explain away one of the committee's key concerns. This gambit did not succeed, because the committee had the competence Grassroots Expertise - 14 
to understand the officials' argument and reject it as an excuse for poor performance. Board members were effective in playing defense by testing the officials' expert claims, but neither their expert style nor their advisory and informational role under the City Charter enabled them to play offense by demanding accountability. Having said their piece, they had nowhere to go. The officials continued to discuss the matter in a factual way - "we do audit" - resulting in an inconclusive exchange. Testing of expertise led to little if any change in power relations.

Another committee member, Maria Vallejo, then introduced a concern over the use of credit ratings in the application process. Morris responded factually by saying that "credit ratings are a big part of the eligibility process," but that some developers set standards that are easier for prospective tenants to meet. Diller interjected that some developers don't use ratings, but only look at judgments against prospective tenants who have failed to pay bills. "It's a good thing that they are going away from credit scores," she said, but "they are allowed to use their own credit criteria." Morris said that HPD is "looking at" the credit criteria they allow developers to use and "we don't disagree with you." Morris also mentioned a task force to look at credit criteria. Boston jumped in quickly to say "I want to be on it," prompting nervous laughter and a noticeable pause from the city officials and board members alike. In contrast to the previous exchange, this discussion moved from the city officials giving simple factual statements, which seemed if anything to defend the developers, toward sincere-seeming statements that the city shared board members' concern. But despite the board's effort to address the officials on a technical, agency staff did not take seriously the suggestion that the advisory and representative committee members could cross over to participate in the agency's technical task force. Nor did committee members, apparently.

After discussing a few other issues, Chairwoman Smith finally asked the officials to comment on the community board's marketing plan - the stated purpose of inviting the officials to attend the meeting. Diller said that "there are many things in the plan that we are in favor of," but that it would have to be modified to create a 60-day period for each development during which only Grassroots Expertise - 15 
the agencies' approved marketing to go on. This, she said, was so that everyone would have the same access. Remarkably, the board did not follow up on this statement to explore how much this requirement would limit the implementation of the community board's marketing plan.

At other meetings and in interviews, board members often said that they wanted to "summon" agency officials and developers or to "grill them," but the committees cannot fully produce the power dynamic implied by this language. They can get officials to meetings and ask them questions, as the city charter provides. They can also advise the agencies as to their priorities. But the committee cannot call agencies to account through the combination of giving instructions and questioning. Agency staff might choose to act in accordance with the board's wishes but will avoid sharing power by revealing information unfavorable to the developers. Nor will they ever admit that their actions had been determined by the board. They represent any action they take as their own decision, leaving the board in situation of chronic uncertainty as to its own effectiveness.

\section{The Problem of Representation}

New York's community boards do not operate in a political vacuum, and therefore their ability to influence, contest, and legitimate expert authority is not solely dependent on direct interactions with developers and agencies. They can also act through their lively relationship with the City Council. Elected officials, including City Council members, appoint the board members, and board members are often involved in electoral politics themselves. The boards operate on a similar spatial scale to the City Council, which means that public opinion formed in the boards can be quite important within a council district. Local City Council members also play a pivotal role in housing and land use decisions. By custom, the City Council as a whole defers to the local member's views on development decisions in the final stage of the ULURP process. In effect, the council member has veto power over developments subject to ULURP, more power than any other player in the entire complicated process. If opinion formed within the board system is strong enough to influence the 
council member's decision, therefore, it can be decisive. Thus its role as a specialized public forum is as important as its role as an advisor of agencies.

This function of the community board is colored by the board's advisory role but also, perhaps more strongly be a representative one. In addition to assessing community needs, board members can also form public opinion by aggregating, deliberating, and communicating community interests. This role is more explicitly public than the advisory one, placing different demands on the board members' styles of self-presentation. Through interviews and by observing a contentious meeting of the full community board, it became clear that representation itself is also a problematic task for board members, especially given that they are chosen by elected officials. Several participants told me that the board is most effective when its wishes are aligned with those of the elected officials. Tanya Smith, for example, said that the board can succeed "if we use [our power] right, if we partner with our elected officials and we're not fighting with them, and when we have elected officials that are truly about the needs of the community and not what will take them to the next level politically." ${ }^{6}$ This rings true because formally powerful City Council members have an electoral incentive to respect preferences legitimated by the Community Board. But alignment between elected officials and the board could just as easily indicate that the former is influencing the latter, and board members themselves may not know which it is.

These issues emerged controversially when the full board voted on a proposal to create protected bike lines on two avenues passing through the neighborhood. The meeting was held at modernist brick and concrete elementary school. Perhaps 100 people were already sitting or standing in the auditorium before the meeting and many more continued to arrive. Behind tables on the wide stage sat District Manager George Sarkissian, Board Chair Michael Jefferson, and other board officers. Other board members took their seats with the public in the audience. Once the 2012.

6 Participant quotations not from public meetings are from interviews conducted in April and May Grassroots Expertise - 17 
meeting's preliminary phases were over, the bike lanes issue took center stage. The Public Safety and Transportation Committee gave its report, recommending that the board support the proposed bike lanes on First and Second avenues. This quickly produced a question from Andrea Boston about whether there had been sufficient public input on the issue. The committee chair, Maggie Garcia, replied that there had been, and Jefferson jumped in, strongly supporting Garcia's answer, as did a representative from the city Department of Transportation (known as DOT). It was evident that Boston opposed the bike lanes, while Garcia and Jefferson supported them.

The two sides initially maintained the kind of third-person discourse already described, sticking to the fiction that they were seeking and providing factual information about the process for public input. This style of presentation harmonizes both with the board members' expert posture toward city agencies and with the tradition of decorum in legislative bodies. All parties in the exchange initially avoided using the words "I" and "you," but this eventually broke down. Boston began talking about her personal concerns, raising the rhetorical stakes by appealing to the need to protect children. Then she addressed board member Coleman Jonas directly and suggested that he was biased on the issue because he works for Transportation Alternatives, a group that supports bike lanes. Jefferson cut her off and tried to redirect the conversation back to process, but Jonas finally got up and said that nobody's integrity or motive should be questioned. Jonas paced a little as he spoke, but kept his hands at his sides. "I work for Transportation Alternatives, but I do not ride a bike," he said. His work for the organization relates to public transportation issues, but he supports bike lanes because he rode bikes when he was a kid.

Then Jonas turned to his most effective bit of rhetoric. Despite the implied criticism of the bike lane opponents, he preserved an upbeat tone of voice. "The same energy we put into a fight against bike lanes we need to put into a fight for own children's education" and a long list of other issues. This produced loud applause from throughout the house. Debra Carter, the board vice-chair sitting on stage, then weighed in, saying that she could support the bike lanes, but only because the Grassroots Expertise - 18 
city has funded the project and it will create jobs. She was less successful in keeping her cool than Jonas - holding the mike with her right hand and gesturing vehemently with her left, speaking loudly, and creating a sense of escalation. She also got applause, coming only from the area where Boston and other bike lane opponents were sitting. After a few more questions, Jefferson said that he was ready "to forward the recommendation of the committee," but a new anti-bike lane speaker, board member and business owner George Barda, rose to say that he believed that the bike lanes would lead to an increase in asthma, and that he had lived "in the community" for 30 years. This produced loud applause from the area where the anti-bike lane people were sitting. The subject matter was drifting further away from process and toward the substance of the pro- and anti-bike lane positions. Jefferson then began trying to wrap up discussion of the bike lane proposal, speaking over the microphone while opponents shouted over him, accusing him of being partisan and onesided, and of not allowing them to speak.

After a brief, tension-diffusing discussion of another matter, Jefferson began to say that he would entertain a motion to forward the recommendation of the committee on the bike lanes. Boston quickly interrupted to bring up some recommendations from a work group that had been distributed at the meeting. Boston made a motion to reject the bike lanes until these recommendations were followed, and it was swiftly seconded. Jonas asked Jefferson to clarify the relationship between this motion and the recommendations. It seemed that he was trying to politely get at the fact that at least one of the recommendations could not be followed without also installing the bike lanes. But Jefferson chose to ignore the motion's problematic construction and described it as a conditional rejection until the recommendations are acted on. A questioner from the floor asked whether the motion on the floor supports bike lanes or not. Jefferson tried to clarify without being partisan, sticking to the "conditional rejection" formulation though many people still seemed to be confused. 
Someone asked if there were two motions on the floor, but Jefferson pointed out that no one had ever made the motion to forward the committee's recommendation, so Boston's motion was the only one on the floor. Someone would have to make a separate motion on the committee's recommendation in order for that to be considered. Boston abruptly rose and withdrew her motion. Maria Vallejo then made a motion to support the bike lanes, and it was seconded. After some clarification of proper wording, Jefferson asked the secretary to call the role. In the end the vote was 21 yes, 14 no, 2 abstentions. Michael quickly moved to pass the rest of the Public Safety and Transportation committee's other items on a single voice vote and move to the next committee. The DOT representative and her staff left quickly in a group.

I subsequently learned that the center of the controversy over this vote was whether City Council Member Melissa Mark-Viverito (who has since become Council Speaker) had improperly influenced it. She took a public position in favor of the bike lanes (Mark-Viverito 2012), and three of my interviewees told me that Mark-Viverito had also called board members about the issue. Two of them, Alice Wing and Tanya Smith, considered this an intrusion on the board's independence, even though Wing supported the bike lanes and Smith opposed them. The other interviewee, Maria Vallejo, supported the lanes and considered the calls an acceptable part of the process. "[E]very time [Mark-Viverito] has called me to support an issue," Vallejo said, "she will say, always at the end, but always, remember, you will do what you think is better."

Unlike some other participants, Vallejo also considered the parliamentary maneuvering around the bike lane vote appropriate. She credited the opponents with good strategy in making their motion first, but faulted them for choosing to sit together in one area so that when they applauded anti-bike speeches, they sounded like a smaller faction than if they had distributed themselves around the hall. "Who organized it?" she asked. She also took credit for her own swift action after pressure from bike lane supporters (as she saw it) caused Andrea Boston to withdraw the anti-bike lane motion. "So the minute that she withdraw," she said, "I - whoop! You saw I didn't Grassroots Expertise - 20 
even allow her to finish, I got up, o-o-h. You got to be fast." Other board members had criticized these parliamentary strategies as a waste of time, but Vallejo saw as appropriate parts of the board's process.

In Vallejo's view, the board's connections to the political world of the elected officials actually contribute to its ability to aggregate interests. If board members were merely tools of the elected officials, she told me, "she would be calling us every month. As it is she call us once a year. ... And they, you know, also, they highly respect the community board. ... They know the people that are there are connected to other people... and those vote for them." Their political relationships of board members are a source of board influence over elected officials, in addition to the influence running the other way. This is plausible for two reasons. First, elected officials may appoint politically minded board members whose votes they can't control precisely because those members' independent profiles make it important to maintain relationships with them. And second, the members' own political relationships could cause them to adopt positions that reflect the views of attentive voters, thus providing elected officials with electorally useful information. But such a delicate arrangement shrouds the board's representative capacity in permanent ambiguity. Board members criticize each other for being political and set up a dichotomy between being "for the community" and "for the politicians" even as they acknowledge that relationships with elected officials give them leverage to translate their advisory power into policy influence.

The board members' conflicted position yields some conspicuous silences in their public performances. Although many board members were well aware of the political machinations surrounding the bike lane issue, none mentioned them during the public consideration of the question, even though they brought forward other highly contentious aspects of the issue. Would open discussion of this matter be inconsistent with the board's self-presentation as an advisory and representative body? It is interesting that board members sometimes slipped in their efforts to 
behave as proper representatives by maintaining the decorous tone of parliamentarians, but they never wavered in abstaining from talking about the behind-the-scenes aspect of the controversy.

\section{Grassroots Expertise and its Limits}

The practices of the East Harlem community board can be seen as deliberative, if that term is defined broadly enough to include political conflict tempered by a reciprocal commitment by the factions to give good reasons for their positions. But this commitment appears to emerge not from participatory-democratic principle but from board members' need to present themselves as proper advisors and representatives. Their efforts to do this involve not only the use of technical terms and concepts but also the adoption of styles of self-presentation that resemble the "scene styles" described by Lichterman and Eliasoph (2014). My observation of the board showed that board members are at least somewhat successful in engaging expert knowledge while working within this scene style. They were able to subject developers' housing development proposals to criticism based on their neighborhood's economic profile, and they were able prevent agency officials from using expert discourse to avoid scrutiny of their actions by the board. In other words, the board's style enabled the public testing of developers' and officials' expert claims by neighborhood residents with interactional expertise. But board members also encountered barriers to their effectiveness -- barriers that relate to members' lack of private information and of authority under the City Charter, but that also involved the entanglement of their interactional expertise with role performance and conformity to the board's scene styles.

First, board members seeking more affordable housing for their neighborhood tried to improve their legitimacy by presenting themselves as expert advisors. Since they were essentially advocating for their community's needs and priorities, they might well have positioned themselves as representatives. But the prestige of expertise within the housing development field led them to translate their input into technical discourse, presenting themselves as experts on their own 
community. When they try to render expert judgment on whether a development proposal provides good enough affordability profile given the limitations of their policy environment, however, they run up against limits. Doing this requires access to information guarded by other parties, especially developers. Knowing their own community, and translating that knowledge into an expert discourse, is not sufficient to display this kind of judgment, leaving the members unable to fully inhabit the advisory role.

Second, the board was stymied in its attempt to combine its advisory and informationgathering roles into control over a city agency. As with the first example, the board seemed to avoid the position of representative, deliberately choosing a style of self-presentation appropriate to advisors. The agency responded in a manner that suggested that board was more like a petitioner or a focus group - a source of information about neighborhood preferences which the agency could process and take account of outside the public eye. The implicit struggle over the board's role took place in part though decorum - efforts on both sides to act in manner appropriate to their preferred role definitions. But as with the first example, lack of information limited the board's effectiveness. The agency made sure that members could not know whether they had succeeded in functioning as monitors of the agency's performance.

Third, when the board rendered an official decision, it adopted a parliamentary style appropriate to its representative role. Board members found it appropriate to make elaborate, though inconsistent, efforts to cast their cast substantive arguments for and against the bike lanes as if they were addressing questions about the decision-making process, and they strictly avoided mentioning behind-the-scenes activities that could undermine their legitimacy as community representatives. Although the board's relationships with elected officials provide the most plausible means for the board to influence policy outcomes, they could not publicly acknowledge this.

In each of these examples, board members sought to influence outcomes by playing roles legitimated for them by the City Charter, whether expert advisor or community representative. In Grassroots Expertise - 23 
the first two examples, a lack of information limited their effectiveness, while in the third case their efforts to acts as proper representatives left them ambivalent about a likely source of political effectiveness. However, informational barriers and ambivalent relationships with elected officials do not provide a sufficient account of the board's predicament. In each case, the board members' effectiveness was impeded by their need to work through role performance.

Sometimes, it was a functional aspect of role performance that tripped members up. Without information that was withheld by the other parties, the board's housing committee could not exercise the kind of judgment that would show them to be proper advisors. But often it was the public, dramaturgical aspect of the needed performances that created the impediment, as board members made conspicuous efforts to use verbal language and body language appropriate to their roles. Perhaps one reason for this emphasis on role performance was the difficulty of establishing a more rationalistic standard for evaluating board member's actions. The board's housing committee could not evaluate its own effectiveness because the city housing agency withheld information, while the board as a whole could not evaluate whether it was influencing or being influenced by elected officials because of members' reluctance to acknowledge the complexity of their relations with the electeds. In each case dramaturgical performance of advisory or representative roles may have served as compensation for the unclarity.

\section{Prospects for Reform}

Members of Manhattan Community Board 11 were able to partially overcome the theoretically expected conflict between expertise and democratic participation. Sustained involvement in the board's committees enabled them to develop technical knowledge as a resource for persuasion, partially leveling the playing field between the interests represented on the board and those of government agencies and developers. In a more limited way, they were also able to

Grassroots Expertise - 24 
acquire the status and legitimacy that comes from the possession of technical knowledge. But they were hampered by the contradictory roles the City Charter and their own scene style assigns them. This analysis suggests several policy responses. First, the members' successes, partial as they are, do indicates that technical capacity produces results for community boards. If boards in other low-income communities have less capacity than the East Harlem board, as is reputed to be the case, then they might well benefit from efforts to bring them up to the East Harlem Board's level. In fact, recent reform initiatives have often taken this tack (Stringer 2007, Municipal Art Society 2010). But such efforts might be initiatives targeted if they were conceived as efforts to increase board members' interactional expertise - that is, their capacity to test and legitimate the expert claims of others - rather than as efforts to provide technical support or include substantive experts on the board, strategies that might make boards more deferential to rather than more critical of expertise.

But because expert legitimacy in this scene is not just the ability to perform analysis but an aspect of social roles, many potentially effective reforms are not based on improving technical capacity at all. The board's ability to persuasively evaluate development proposals was limited by its inability to compare proposed affordability levels to realistic alternatives, resulting from a lack of information about developers' costs and subsidy availability. This could be remedied by stronger disclosure requirements for developers and agencies. The boards' shortage of authority is a more difficult barrier to overcome, given that the city already has legitimate democratic procedures for making land use decisions within the electoral sphere. But perhaps changes in the boards' procedures and work products could foreground their role as testers and legitimators of expert claims instead of positioning the board as a sort of legislature without legislative authority. Instead of simply taking an up or down position on land use applications and other questions, the board could pass a more detailed resolution including evaluations of expert claims made for against a 
proposal. By doing this, the board would be directly claiming and affirming its useful role in the testing and legitimation of expertise.

\section{References}

Advisory Commission on Intergovernmental Relations. 1979. Citizen Participation in the American Federal System. Washington, D.C.: Advisory Commission on Intergovernmental Relations.

Arnstein, Sherry R. 1969. "A Ladder of Citizen Participation," Journal of the American Institute of Planners 35 (4): 216-224.

Berry, Jeffrey M., Kent E. Portney, and Ken Thomson. 1993. The Rebirth of Urban Democracy. Washington, D.C.: Brookings Institution.

Chaskin, Robert J., and Ali Abunimah. 1999. "A View from the City: Local Government Perspectives on Neighborhood-Based Governance in Community-Building Initiatives," Journal of Urban Affairs 21(1): 57-78.

Collins, H.M., and Robert Evans. 2002. "The Third Wave of Science Studies: Studies of Expertise and Experience," Social Studies of Science 32 (2), 235-296.

Cooper, Terry L., Thomas A. Bryer, and Jack W. Meek. 2006. "Citizen-Centered Collaborative Public Management." Public Administration Review 66 (s1): 76-88.

Davila, Arlene. 2004. Barrio Dreams: Puerto Ricans, Latinos, and the Neoliberal City. Berkeley, Calif.: Univ. of California Press.

Dewey, John. 1927 (1954). The Public and its Problems. Athens, O.: Swallow Press.

Dzur, Albert W. 2004. "Democratic Professionalism: Sharing Authority in Civic Life," The Good Society 13 (1): 6-14.

Epstein, Steven. 1995. "The Construction of Lay Expertise: AIDS Activism and the Forging of Credibility in the Reform of Research Trials," Science, Technology, and Human Values 20 (4), 408-437.

Fung, Archon. 2006. "Varieties of Participation in Complex Governance," Public Administration Review 66 (s1): 66-75.

Fung, Archon, and Erik Olin Wright. 2001. "Deepening Democracy: Innovations in Empowered Participatory Governance," Politics and Society 29 (1): 5-41.

Furman Center for Real Estate and Urban Policy. 2011. State of New York City's Housing and Neighborhoods 2011. New York: author.

Gaventa, John, and Andrea Cornwall. 2001. "Power and Knowledge," in Peter Reason and Hilary Bradbury (eds.), Handbook of Action Research: Participative Inquiry and Practice. London: Sage Publications.

Hayward, Clarissa Ryle. 2004. "Doxa and Deliberation," Critical Review of International Social and Political Philosophy. 7(1) 1-24.

Hum, Tarry. 2010. "Planning in Neighborhoods with Multiple Publics: Opportunities and Challenges for Community-Based Nonprofit Organizations," Journal of Planning Education and Research 20, 1-17.

Jones, Peris S. 2003. “Urban Regeneration's Poisoned Chalice: Is there an Impasse in (Community) Participation-based Policy?" Urban Studies 40 (3), 581-601.

Jun, Kyu-Nahm, and Juliet Musso. 2013. "Participatory Governance and the Spatial Representation of Neighborhood Issues," Urban Affairs Review 49(1): 71-110.

Grassroots Expertise - 26 
Lee, Caroline W., Edward T. Walker, and Michael McQuarrie. 2015. Democratizing Inequalities: Dilemmas of the New Public Participation. New York: New York Univ. Press.

Levine, Jeremy R. 2017. "The Paradox of Community Power: Cultural Processes and Elite Authority in Participatory Governance." Social Forces 95(3): 1155-1179.

Lichterman, Paul, and Nina Elisasoph. 2014. "Civic Action,” American Journal of Sociology 120 (3), 798-863.

Looker, Benjamin. 2015. A Nation of Communities: Imagining Cities, Communities, and Democracy in Postwar America. Chicago: Univ. of Chicago Press.

Marcuse, Peter. 1987. "Neighborhood Policy and the Distribution of Power: New York City's Community Boards," Policy Studies Journal 16 (2): 277-289.

Marcuse, Peter. 1990. "New York City's Community Boards: Neighborhood Policy as Results," in Neighborhood Policy and Programmes, edited by Naomi Carmon, 145-156. New York: St. Martin's Press.

Mark-Viverito, Melissa. 2012. "If Park Slope Gets a Bike Lane, Why Not East Harlem?" New York Daily News, January 6.

Municipal Art Society. 2010. Planning for All New Yorkers: A 21st Century Upgrade for New York's Planning Process, Recommendations of the Community-Based Planning Task Force Prepared by the Municipal Art Society. New York: author.

New York City Affairs. 1980. "Community Boards: How Are We Doing?" (special issue).

New York City Charter, Chapter 70 (City Government in the Community), Section 2800 (Community Boards). Accessed March 28, 2014, law.onecle.com/new-york/new-york-citycharter/NYC02800_2800.html

Office of Management and the Budget 2011. City of New York Adopted Budget Fiscal Year 2012: Expense Revenue Contract. New York: City of New York Office of Management and the Budget, accessed March 28, 2014, www.nyc.gov/html/omb/downloads/pdf/erc6_11.pdf

Pecorella, Robert F. 1994. Community Power in a Postreform City: Politics in New York City. Armonk, N.Y.: M.E. Sharpe.

Stringer, Scott M. 2007. "A Community of Experts." The New York Times, June 10.

Swyngedouw, Erik. 2005. "Governance Innovation and the Citizen: The Janus Face of GovernanceBeyond-the-State," Urban Studies 42 (11), 1991-2006.

Taylor, Marilyn. 2007. "Community Participation in the Real World: Opportunities and Pitfalls in New Governance Spaces.” Urban Studies 44 (2), 297-317.

Turner, Stephen. 2001. "What is the Problem with Experts?" Social Studies of Science 31 (1), 123149.

Williams, Timothy. 2006. "Bronx Board Is Shuffled After Rejecting New Stadium," The New York Times, June 19.

Wynne, Brian. 1992. "Misunderstood Misunderstanding: Social Identities and Public Uptake of Science," Public Understanding of Science 1, 281-304.

Yates, Douglas. 1973. Neighborhood Democracy: The Politics and Impacts of Decentralization. Lexington, Mass.: Lexington Books.

Young, Iris Marion. 2000. Inclusion and Democracy. Oxford: Oxford Univ. Press. 